\title{
Weed Control Via Intercropping With GliRicidia. I. CotTon CROP $^{1}$
}

\author{
Controle de Plantas Daninhas por Meio da Consorciação com Gliricídia. I. Cultura do \\ Algodoeiro
}

\begin{abstract}
SILVA, P.S.L. ${ }^{2}$, SILVA, J.C.V. ${ }^{3}$, CARVALHO, L.P. ${ }^{4}$, SILVA, K.M.B. ${ }^{5}$ e FREITAS, F.C.L. ${ }^{6}$
ABSTRACT - The majority of cotton grown commercially in the world has white lint, but recently, there has been a growing interest in colored lint cotton in several countries, including Brazil. The use of naturally-colored fiber reduces chemical pollution. The objective of this paper was to evaluate cotton cultivar fiber yield in response to weed control via intercropping with gliricidia. Cultivars $B R S-V e r d e$ (greenish fibers), BRS-Rubi (reddish brown fibers), BRS-Safira (brown fibers), and BRS-187 8H (white fibers) were submitted to the following treatments: no hoeing, two hoeings (at 20 and 40 days after transplanting), and cotton intercropped with gliricidia. In the intercropped treatment, gliricidia was planted between rows of cotton plants, using one seedling pit in $^{-1}$ in pits spaced $50.0 \mathrm{~cm}$ apart. Twelve weed species predominated in the experiment, many of them belonging to the Poaceae family. Weeds occurred at different frequencies and in a non-uniform manner in the experimental area. Cultivars did not influence weed dry matter. Intercropping with gliricidia reduced weed dry matter but did not prevent reductions in cotton fiber and seed cotton yield, which were higher in hoed plots. Cultivar BRS Safira had the highest fiber yield, but no differences were observed between cultivars regarding to seed cotton yield.
\end{abstract}

Keywords: naturally-colored cotton fiber, Gliricidia sepium, cultivars.

\begin{abstract}
RESUMO - A grande maioria do algodoeiro cultivado comercialmente no mundo possui fibra branca, porém atualmente existe crescente interesse em diversos países, inclusive no Brasil, pelo algodão de fibra colorida. O uso de fibras naturalmente coloridas reduz a poluição química, por dispensar o uso de corantes. O objetivo deste trabalho foi avaliar o rendimento de fibras de cultivares de algodoeiro em resposta ao controle de plantas daninhas por meio da consorciação com a gliricídia (Gliricidia sepium). Os cultivares BRS-Verde (fibras esverdeadas), BRS-Rubi (fibras marrons avermelhadas), BRS-Safira (fibras amarronzadas) e BRS-187 8H (fibras brancas) foram submetidos aos seguintes tratamentos: sem capinas, duas capinas (aos 20 e 40 dias após o transplantio) e consorciação do algodoeiro com a gliricídia. Na consorciação, a gliricídia foi plantada entre as fileiras do algodoeiro, usandose uma plântula por cova, em covas espaçadas por 0,50 m. Doze espécies de plantas daninhas ocorreram no experimento, a maioria delas pertencente à família Poaceae. As plantas daninhas ocorreram com diferentes frequências, distribuídas desuniformemente na área experimental. Os cultivares não influenciaram a matéria seca das plantas daninhas. A consorciação com a gliricídia reduziu a matéria seca das plantas daninhas, mas não evitou reduções nos rendimentos de algodão em fibra e em caroço, que foram maiores nas parcelas que receberam capinas. O cultivar BRS-Safira apresentou o maior rendimento de fibras, porém não houve diferenças entre cultivares quanto ao rendimento de algodão em caroço.
\end{abstract}

Palavras-chave: algodão de fibra naturalmente colorida, Gliricidia sepium, cultivares.

1 Recebido para publicação em 20.5.2008 e na forma revisada em 18.2.2009.

2 Universidade Federal do Semi-Árido - UFERSA, Caixa Postal 137, 59625-900 Mossoró-RN, CNPq fellow, <paulosergio@ufersa.edu.br>; ${ }^{3}$ UFERSA, CNPq fellow, <julio-ufersa@hotmail.com>; ${ }^{4}$ Embrapa-Algodão. Rua Osvaldo Cruz, 1143, Bairro Centenário, 58107-720 Campina Grande-PB, Brazil, <carvalho@ cnpa.embrapa.br >; ${ }^{5}$ Universidade do Estado do Rio Grande do Norte - UERN, Caixa Postal 70, 59610-090 Mossoró RN, <kmbsbarbosa@yahoo.com.br>; ${ }^{6}$ UFERSA, $<$ franciscoclaudio@ufersa.edu.br> 


\section{INTRODUCTION}

Cotton, the most important natural fiber, is of prime importance for the economy of many countries. It is the world's leading fiber crop with an annual production of 20 million tones and it is grown in more than 20 countries (Dutt et al., 2004). Until the 1980s, cotton was one of the most important crops grown in Brazil. Since then, exploitation of cotton crop has progressively declined in Brazil due to boll weevils, which became the major cotton pest. In recent years, several control methods have allowed the crop to coexist with boll weevils, and growers are beginning to exploit it once again.

Colored cotton is a naturally pigmented fiber. Shades of colored cotton can vary over seasons and geographic location due to climate and soil variations. Colored cotton has been grown and used by man since $2500 \mathrm{BC}$ (Wanghmare \& Koranne, 1998). Cultivation of colored cotton was discouraged and almost abandoned in the last half of the $20^{\text {th }}$ century because of its low productivity, poor fiber quality and non-uniformity of colors (Dutt et al., 2004). With the concentrated research efforts over the last 50 years, superior white lint cultivars have been developed. These cultivars cover the majority of the cotton-grown area. Most cotton grown commercially in the world has white lint, but recently there is a growing interest in colored lint cotton in several countries (Dutt et al., 2004, Punitha \& Raveendran, 2004), including Brazil (Carvalho et al., 2005).

During the process of bleaching and dyeing of white lint cotton to impart colors, dyeing and textile units regularly use several toxic chemicals including heavy metals. The water from these units is a main source of pollution in drinking water, soil and environment. Many of these chemicals are carcinogenic and may cause allergies, skin rashes and other related health problems to human beings (Dutt et al., 2004). Naturally colored fiber reduces chemical pollution. Therefore, increased attention has being paid to studies of colored cotton and its utilization around the world.

The adoption of intercropping system is usually justified by the better use of environmental resources as compared to monocropping (Fukai \& Trenbath, 1993). In addition, intercropping is also indicated as an alternative to the use of herbicides, by reducing or suppressing weed growth. A reduction in herbicide use is one of the main interests of modern agriculture and several alternatives are being investigated with this objective, including intercropping (Carruthers et al., 1998).

As an alternative to the existing shifting cultivation systems in the tropics, farmers are being encouraged to adopt agro forestry systems in which trees contribute pruning which may be used to mulch the associated crops. Gliricidia sepium (Jacq.) Walp, Leucaena leucocephala (Lam.) de Wit and Senna siamea (Lam.) Irwin \& Barneby are trees widely tested for agro forestry technologies (Kamara et al., 2000). However, in addition to soil improvement, mulching material also suppresses weed growth (Budelman, 1988). Weed growth has been shown to be suppressed in alley cropping by canopy closure (Yamoah et al., 1986). Besides physically suppressing the weeds, plant residues decomposition can also release phytotoxic compounds that inhibit crop and weed growth (Tian \& Kang, 1994). Plant species differ in their response to phytotoxic plant residues. G. sepium mulch had no allelopathic effect on maize or beans but significantly decreased the population of some weed species (Obando, 1987). Mulches from $G$. sepium and $S$. siamea reduced weed density and weed biomass, while L. leucocephala was less effective at reducing weed biomass and density (Kamara et al., 2000).

This study investigated a new type of intercropping, i.e., the use of an arboreal legume to control weeds in cotton. No data were found in the literature comparing soil cover and intercropping on weed control in cotton. In rice, though the dry weight of grass weeds at 30 days after seeding was lower with intercropping with Sesbania rostrata than with wheat residue mulch, they were similar at later stages. A lower broadleaved weed density and dry weight were observed with Sesbania than with mulch. It was concluded that application of wheat residue mulch at $4 \mathrm{t} \mathrm{ha}^{-1}$ and Sesbania intercropping for 30 days was equally effective in controlling weeds associated with dry-seeded rice (Singh et al., 2007). 
The objective of this paper was to evaluate cotton cultivar fiber yield in response to weed control via intercropping with gliricidia.

\section{MATERIAL AND METHODS}

The experiment was carried out at the "Rafael Fernandes" Experimental Farm at the Universidade Federal Rural do Semi-Árido (UFERSA), $20 \mathrm{~km}$ from the county seat, in Mossoró-RN ( $5^{\circ}$ ' latitude, $37^{\circ}$ 20' WGr longitude and an altitude of $18 \mathrm{~m}$ ), Brazil, using sprinkler irrigation. According to Köppen, the region's bioclimate is BSwh.

Cotton and gliricidia were grown in a transplantation system. Seeding was performed in Styrofoam trays with cells $(35 \mathrm{~mL}$ volume) on 06.14 .06 . The substrate was prepared with 2/3 of a soil classified as Arenic Hapludult (Red -Yellow Argisol - PVA), and 1/3 vermicompost (humus). Analysis of the soil indicated $\mathrm{pH}=7.20 ; \mathrm{P}=51.97 \mathrm{mg} \mathrm{kg}^{-1} ; \mathrm{K}^{+}=$ $0.20 \mathrm{cmol}_{\mathrm{c}} \mathrm{dm}^{-3} ; \mathrm{Ca}^{2+}=4.50 \mathrm{cmol}_{\mathrm{c}} \mathrm{dm}^{-3} ; \mathrm{Mg}^{2+}=$ $1.60 \mathrm{cmol}_{\mathrm{c}} \mathrm{dm}^{-3} ; \mathrm{Al}^{3+}=0.00 \mathrm{cmol}_{\mathrm{c}} \mathrm{dm}^{-3} ; \mathrm{Na}^{+}=$ $0.10 \mathrm{cmol}_{\mathrm{c}} \mathrm{dm}^{-3}$. Analysis of a humus sample indicated: $\mathrm{pH}=7.90 ; \mathrm{P}=120.1 \mathrm{mg} \mathrm{kg} \mathrm{kg}^{-1} ; \mathrm{K}^{+}$ $=0.67 \mathrm{cmol}_{\mathrm{c}} \mathrm{dm}^{-3} ; \mathrm{Ca}^{2+}=19.50 \mathrm{cmol}_{\mathrm{c}} \mathrm{dm}^{-3} ; \mathrm{Mg}^{2+}$ $=15.00 \mathrm{cmol}_{\mathrm{c}} \mathrm{dm}^{-3} ; \mathrm{Al}^{3+}=0.00 \mathrm{cmol}_{\mathrm{c}} \mathrm{dm}^{-3} ; \mathrm{Na}^{+}=$ $0.19 \mathrm{cmol}_{\mathrm{c}} \mathrm{dm}^{-3}$. Both crops were transplanted to the permanent site simultaneously, two to three days after emergence. The analysis of a soil sample from the permanent site, also classified as Arenic Hapludult (PVA), indicated: $\mathrm{pH}=6.70 ; \mathrm{P}=60.70 \mathrm{mg} \mathrm{kg}^{-1} ; \mathrm{K}^{+}=$ $0.21 \mathrm{cmol}_{\mathrm{c}} \mathrm{dm}^{-3} ; \mathrm{Ca}^{2+}=4.20 \mathrm{cmol}_{\mathrm{c}} \mathrm{dm}^{-3} ; \mathrm{Mg}^{2+}=$ $1.60 \mathrm{cmol}_{\mathrm{c}} \mathrm{dm}^{-3} ; \mathrm{Al}^{3+}=0.00 \mathrm{cmol}_{\mathrm{c}} \mathrm{dm}^{-3} ; \mathrm{Na}^{+}=$ $0.18 \mathrm{cmol}_{\mathrm{c}} \mathrm{dm}^{-3}$. Soil tillage was accomplished with a tractor, by means of two cross harrowings, and received $30 \mathrm{~kg} \mathrm{~N}$ (1/3 of total $\mathrm{N}$ applied), $60 \mathrm{~kg} \mathrm{P}_{2} \mathrm{O}_{5}$, and $30 \mathrm{~kg} \mathrm{~K} \mathrm{O}_{2}$ per ha as planting fertilization. The remaining $\mathrm{N}$ was applied in equal parts after each hoeing. Ammonium sulfate, single super phosphate, and potassium chloride were applied as sources of $\mathrm{N}, \mathrm{P}_{2} \mathrm{O}_{5}$, and $\mathrm{K}_{2} \mathrm{O}$, respectively.

Pest control was performed with two deltamethrin sprays $\left(250 \mathrm{~mL} \mathrm{ha}^{-1}\right)$ at 7 and fifteen days after transplanting, respectively. The experiment was sprinkler-irrigated, with experimental plots arranged perpendicularly in relation to the row of sprinklers. The water depth required for cotton $(5.6 \mathrm{~mm})$ was calculated considering a root-system effective depth of $0.40 \mathrm{~m}$. Irrigation timing was based on water retained by the soil at a tension of $0.40 \mathrm{MPa}$. A two-day watering schedule was adopted, with three weekly applications. Irrigations were initiated after transplanting and suspended after the first bolls opened.

A randomized block experimental design in split-plot with five replicates was adopted. Each subplot consisted of four rows, each $6.0 \mathrm{~m}$ in length. The area occupied by the two central rows was considered as usable area, and one pit at the end of each central row was eliminated. Cultivars BRS-Verde, BRS-Rubi, BRS-Safira, and BRS-187 8H (assigned to the plots) were submitted to the following treatments: no hoeing, two hoeings (at 20 and 40 days after transplanting), and cotton intercropped with gliricidia. The cotton seeds were supplied by EMBRAPA's Centro Nacional de Pesquisa do Algodão (National Center for Cotton Research), including the information provided below for each cultivar; gliricidia seeds were supplied by Assessoria e Serviços a Projetos em Agricultura Alternativa (AS-PTA Consulting and Services for Alternative Agriculture Projects), a non-governmental organization with a branch in Campina Grande-PB. Cultivar BRS-Verde resulted from a cross between white-fiber cultivar CNPA 7H and the Arkansas Green cultivar, introduced from the USA, and has greenish fibers, with a resistance of $25.9 \mathrm{gf} \mathrm{tex}^{-1}$ and a $2.5 \%$ span length of $29.6 \mathrm{~mm}$. Here, gf refers to gram force or gram weight, which is the force necessary to give 1.0 gram an acceleration of $980 \mathrm{~cm} \mathrm{~s}^{-2}$, 1.0 tex $=1 \mathrm{mg} \mathrm{m}^{-1}$ (Fonseca \& Santana, 2002) and $2.5 \%$ span length means that at least $2.5 \%$ of total fibers have length exceeding this value (Basra, 1999). Cultivar BRS Rubi resulted from a cross between a material introduced from the USA, which had dark brown fiber, and cultivar CNPA $7 \mathrm{H}$, having reddish brown fibers, with a resistance of $24.5 \mathrm{gf} \mathrm{tex}^{-1}$ and a $2.5 \%$ span length of $25.4 \mathrm{~mm}$. BRS Safira resulted from a cross between the same material introduced from the USA that gave origin to BRS Rubi, and white-fibered cultivar CNPA 8733 , having brown fibers, with a resistance of $24.2 \mathrm{gf} \mathrm{tex}^{-1}$ and a $2.5 \%$ span length of $24.2 \mathrm{~mm}$. White-fibered BRS $1878 \mathrm{H}$ came from line CNPA 86-1190-5, which resulted from a cross 
between lines CNPA 77/ 105 and the American $\mathrm{D}_{3}-79$. Weeding was performed with a hoe, and the same worker was assigned to do the service in each block. In the intercropped treatment, gliricidia was planted at the same cotton transplantation time, between the cotton plant rows, using one seed pit $^{-1}$, in pits spaced $50.0 \mathrm{~cm}$ apart.

Plant height and first branch height were measured in all plants in the usable area of each subplot, after the last harvest of open bolls. The distance from ground level to the upper end of the plant was considered as plant height. Cotton yield was evaluated by weighing and counting all open bolls harvested from the usable area of each subplot. Fiber and seed cotton yield were estimated from a sample of approximately $500 \mathrm{~g}$. Fiber and seed cotton yield were corrected to $10 \%$ moisture content.

Gliricidia dry biomass of the above-ground part and plant height were evaluated in samples consisting of three plants randomly taken from each subplot. In order to estimate dry biomass, plants were placed in a forced air circulation oven adjusted to $75{ }^{\circ} \mathrm{C}$ until constant weight was achieved. Plant height was evaluated by measuring the distance from ground level to the upper end of the plant.

Weeds were collected in a $1.0 \mathrm{~m} \times 0.8 \mathrm{~m}$ area, in the central part of each subplot, cut even with the ground. Weeds were botanically identified and evaluated for dry biomass of the above-ground part. Based on the botanical identification data, the index of occurrence was calculated as the ratio between the number of subplots where the species occurred and the total number of experimental subplots (60). Dry biomass of the above-ground part of weeds was obtained by a similar procedure as the one used to obtain gliricidia dry biomass.

The data were submitted to analysis of variance using software developed by Universidade Federal de Viçosa (Ribeiro Júnior, 2001), and means were compared by the Tukey test at $5 \%$ probability. The percentage data were transformed to arc sin square root percentage before analysis.

\section{RESULTS AND DISCUSSION}

Only twelve weed species occurred in the experiment (Table 1), most of them belonging

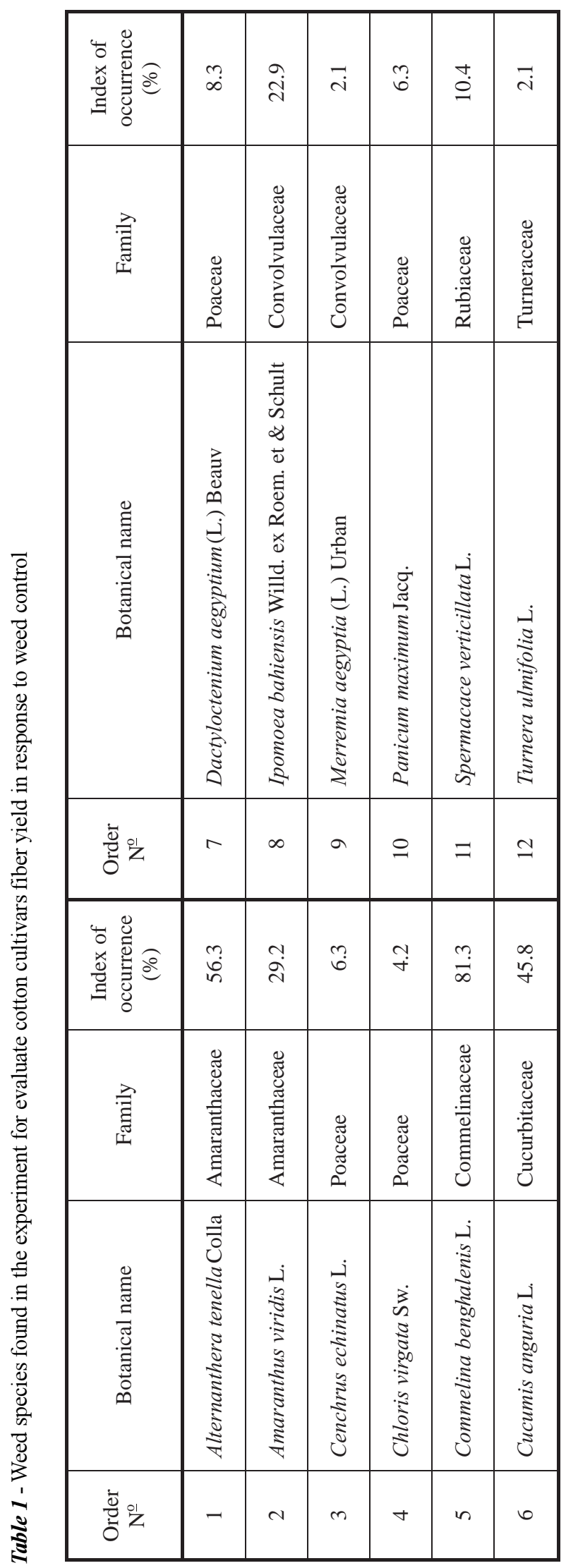


to the family Poaceae. Such small number of species could be associated with the intensive cultivation of corn in the area where the experiment was conducted (two cultivations per year, for almost ten years). Usually, weed biomass production, as well as weed density and diversity, are smaller in traditional cultivations (intensive soil tillage and high doses of chemical products), intermediate in reduced tillage systems, and higher in organic systems (Menalled et al., 2001). Weed population in a given area depends on several factors, and although the population comprises different species, few of them are predominant, corresponding from 70 to $90 \%$ of the total species (Buhler, 1999). Some species occurred more frequently than others. The species Commelina benghalensis, for example, occurred in $85 \%$ of the experimental units, while the species Acanthospermum hispidum, Merremia aegyptia, and Turnera ulmifolia occurred at frequencies lower than $2 \%$ (Tables 1 and 2).

The species were not uniformly distributed over the experimental field (Table 2). Lack of uniformity occurred among blocks, among plots of the same block, and among subplots of the same plot. Block 1, for example, presented $77 \%$ of the species found (Table 1), while block 4 only $46 \%$. In block 2 , the plot cultivated with BRS Verde had only $23 \%$ of the weed species, whereas twice that percentage was found in plots grown with BRS Safira and BRS Rubi. The number of weed species was frequently higher in non-hoed and intercropped subplots than in hoed plots. It is likely that the treatments had some influence on weed species distribution, but other factors, especially those associated with soil (humidity, fertility, seedbank, etc.) were also involved.

There was no effect of cultivars $\times$ weed control interaction on the evaluated characteristics. For this reason, only the means for the main effects of both treatment groups are presented here (Tables 3 and 4).

The cultivars did not influence mean dry matter of the above-ground part of weeds $\left(304.3 \mathrm{~g} \mathrm{~m}^{2}\right)$ and gliricidia mean plant height $(83 \mathrm{~cm})$, but did influence dry matter of the above-ground part of this legume (Table 3). Cultivar BRS Rubi reduced gliricidia plant height the most. Cultivar BRS Rubi also 
showed the lowest plant-height (together with cultivar BRS Verde) and first-branch-height values (Table 3). Cultivar BRS $1878 \mathrm{H}$ had the highest fiber and open-boll weights, but cultivar BRS Safira had the highest fiber yield. Although there were no differences between cultivars as to number of open bolls per plant, a higher number of open bolls per plant was seen in cultivar BRS Safira, which showed the highest fiber yield. There were no differences between cultivars with regard to seed cotton yield (Table 3).

Hoeing decreased dry matter of the aboveground part of weeds and first branch height (lower branch) in cotton (Table 4). Reduction in growth of the above-ground part of weeds is obvious when hoeing is adopted, but there is no plausible explanation for the reduction in first branch height in cotton. Maybe the competition with weeds at the initial stages of cotton growth determines some plant etiolating in the crop, resulting in greater distance between the ground level and the insertion point of the first branch. This initial period of cotton growth contrasts with the high growth rates of weeds (Freitas et al., 2002). On the other hand, weed control by hoeing determined greater plant height, fiber yield, seed cotton yield, and number of open bolls per plant, but did not influence fiber weight open-boll-1 ${ }^{-1}$ or open-boll weight.

The coefficient value of experimental variation for weed dry matter data was relatively high (Tables 3 and 4). The lack of uniformity in weed distribution among plots of the same block may have contributed to this high coefficient, but other factors might have been involved, including the sample size taken for dry matter weed evaluation (LeClerg et al., 1966).

Crop yield reduction due to weed presence is attributed to competition for water, nutrients, and light (Carruthers et al., 1998). In the present work, since the crop was irrigated, competition for water might have been negligible. On the other hand, the removal of nutrients by weeds may have had an impact on the availability of nutrients for the crop. For example, in maize, $\mathrm{N}$ absorption by weeds varied from $32.4 \mathrm{~kg} \mathrm{ha}^{-1}$ to $52.3 \mathrm{~kg} \mathrm{ha}^{-1}$, depending on the type of weed control; in the case of $\mathrm{P}_{2} \mathrm{O}_{5}$, varied from $4.3 \mathrm{~kg} \mathrm{ha}^{-1}$ to $7.2 \mathrm{~kg} \mathrm{ha}^{-1}$ and in the case of $\mathrm{K}_{2} \mathrm{O}$, from $32.1 \mathrm{~kg} \mathrm{ha}^{-1}$ to $38.9 \mathrm{~kg} \mathrm{ha}^{-1}$. Competition for light must be intense at the initial stages of cotton growth due to the previously-mentioned growth differences between cotton and weeds. After those stages, cotton reaches greater height than most weeds, so competition for light should be smaller and limited to the lower leaves, except in the case of "climbing-type" weeds.

In addition, weeds can reduce growth of the crop's root system (Gomes et al., 2007). Due to a limited root system, the plant has smaller capacity to absorb nutrients, resulting in smaller growth of the above-ground part, with a consequent reduction in total photosynthesis (Silva et al., 2004).

Reductions in cotton plant height and cotton yield caused by weeds in the present work were also observed by other authors (Freitas et al., 2002). However, several authors observed cotton yield reductions around 90\% (Freitas et al., 2002), while a reduction of

Table 3 - Means obtained for dry matter of the above-ground part of weeds and traits of gliricidia plants and cotton cultivars (means of four replicates and three "weed control treatments")

\begin{tabular}{|c|c|c|c|c|c|c|c|c|}
\hline Cultivars & $\begin{array}{l}\text { Dry matter of } \\
\text { above-ground } \\
\text { part of } \\
\text { gliricidia } \\
\text { (g per plant) }\end{array}$ & $\begin{array}{c}\text { Plant height } \\
(\mathrm{cm})\end{array}$ & $\begin{array}{l}\text { Height of } \\
\text { first branch } \\
\quad(\mathrm{cm})\end{array}$ & $\begin{array}{l}\text { Fiber w eight } \\
\text { (g per open } \\
\text { boll) }\end{array}$ & $\begin{array}{c}\text { Open boll } \\
\text { weight } \\
\text { (g per open } \\
\text { boll) }\end{array}$ & $\begin{array}{c}\text { Fiber yield } \\
\left(\mathrm{kg} \mathrm{ha}^{-1}\right)\end{array}$ & $\begin{array}{c}\text { № open bolls } \\
\text { per plant }\end{array}$ & $\begin{array}{l}\text { Seed cotton } \\
\quad\left(\mathrm{kg} \mathrm{ha}^{-1}\right)\end{array}$ \\
\hline BRS $1878 \mathrm{H}$ & $19.2 \mathrm{ab}$ & $148 \mathrm{a}$ & $19.0 \mathrm{a}$ & $1.93 \mathrm{a}$ & $5.48 \mathrm{a}$ & $1036 \mathrm{ab}$ & $10.28 \mathrm{a}$ & $2790 \mathrm{a}$ \\
\hline BRS Rubi & $8.4 \mathrm{~b}$ & $126 \mathrm{~b}$ & $15.0 \mathrm{~b}$ & $1.23 \mathrm{c}$ & $3.76 \mathrm{c}$ & $758 \mathrm{~b}$ & $12.68 \mathrm{a}$ & $2307 \mathrm{a}$ \\
\hline BRS Safira & $51.1 \mathrm{a}$ & $140 \mathrm{ab}$ & $17.0 \mathrm{ab}$ & $1.55 \mathrm{~b}$ & $4.38 \mathrm{~b}$ & $1088 \mathrm{a}$ & $13.29 \mathrm{a}$ & $2975 \mathrm{a}$ \\
\hline BRS Verde & $36.0 \mathrm{ab}$ & $138 \mathrm{~b}$ & $16.0 \mathrm{ab}$ & $1.41 \mathrm{bc}$ & $4.22 \mathrm{~b}$ & $781 \mathrm{~b}$ & $9.91 \mathrm{a}$ & $2261 \mathrm{a}$ \\
\hline CVplot, \% & 59.6 & 12.4 & 17.2 & 13.6 & 7.8 & 25.5 & 16.2 & 28.4 \\
\hline
\end{tabular}

Means followed by the same letter do not differ at $5 \%$ probability by Tukey test. 
Table 4 - Means obtained for dry matter of the above-ground part of weeds and characteristics of cotton cultivars in response to weed control method (means of four replicates and four cotton cultivars)

\begin{tabular}{|l|c|c|c|c|c|c|c|c|}
\hline $\begin{array}{c}\text { Method of weed } \\
\text { control }\end{array}$ & $\begin{array}{c}\text { Weed dry } \\
\text { matter } \\
\left(\mathrm{g} \mathrm{m}^{-1}\right)\end{array}$ & $\begin{array}{c}\text { Height of } \\
\text { first branch } \\
(\mathrm{cm})\end{array}$ & $\begin{array}{c}\text { Plant height } \\
(\mathrm{cm})\end{array}$ & $\begin{array}{c}\text { Fiber yield } \\
\left(\mathrm{kg} \mathrm{ha}^{-1}\right)\end{array}$ & $\begin{array}{c}\text { Seed cotton } \\
\left(\mathrm{kg} \mathrm{ha}^{-1}\right)\end{array}$ & $\begin{array}{c}\text { No open bolls } \\
\text { per plant }\end{array}$ & $\begin{array}{c}\text { Fiber weight } \\
(\mathrm{g} \text { per open } \\
\text { boll })\end{array}$ & $\begin{array}{c}\text { Open boll } \\
\text { weight } \\
(\mathrm{g} \text { per open } \\
\text { onll) }\end{array}$ \\
\hline Hand-weeding & $27.4 \mathrm{c}$ & $15.5 \mathrm{~b}$ & $143 \mathrm{a}$ & $1129 \mathrm{a}$ & $3362 \mathrm{a}$ & $15.75 \mathrm{a}$ & $1.57 \mathrm{a}$ & $4.60 \mathrm{a}$ \\
\hline With G. sepium & $353.4 \mathrm{~b}$ & $17.4 \mathrm{a}$ & $136 \mathrm{ab}$ & $841 \mathrm{~b}$ & $2244 \mathrm{~b}$ & $9.89 \mathrm{~b}$ & $1.62 \mathrm{a}$ & $4.40 \mathrm{a}$ \\
\hline No-weeding & $562.0 \mathrm{a}$ & $17.4 \mathrm{a}$ & $135 \mathrm{~b}$ & $776 \mathrm{~b}$ & $2143 \mathrm{~b}$ & $9.00 \mathrm{~b}$ & $1.48 \mathrm{a}$ & $4.38 \mathrm{a}$ \\
\hline CV & 52.1 & 8.7 & 6.5 & 16.5 & 17.2 & 9.9 & 16.0 & 14.7 \\
\hline
\end{tabular}

Means followed by the same letter do not differ at $5 \%$ probability by Tukey test.

approximately $31 \%$ was observed in the present work (Table 4). Obviously, varietal and environmental factor differences could be responsible for these yield reduction differences. Nonetheless, an important factor must have been the irrigation used in the present work. Weed density and biomass could be smaller in irrigated (as in the present work) than in non-irrigated experiments, due to a greater capacity of the crop to suppress weeds when irrigated (Sankula et al., 2004).

Weed dry matter was smaller in plots intercropped with gliricidia than in non-hoed plots (Table 4). Nevertheless, the means for all cotton characteristics in both of these treatments were statistically equal (Table 4). This means that gliricidia controlled weeds, although such control was not sufficient to prevent cotton yield losses. In terms of dry mass of the above-ground part of weeds, weed control provided by gliricidia amounted to $37 \%$. It must be pointed out that the gliricidia plants were spaced $50 \mathrm{~cm}$ from each other. It should be pointed out that these plants might exert better control over weeds when row spacing between them is reduced.

Greater competitive ability of a species in competition with other species should depend on the characteristics of plants of both species (McDonald, 2003; Bertholdsson, 2005) (cotton-gliricidia and gliricidia-weeds, for example, in this work) and environmental conditions (Lemerle et al., 2001). With regard to cotton-gliricidia competition, excluding those characteristics related to gliricidia and environmental conditions, it is interesting to speculate why some varieties of cotton reduced the growth of gliricidia (Table 3). Plant height is often given as an important competitive characteristic. That does not seem to be the case in this study, because cotton cultivars with greater or smaller plant height reduced gliricidia growth. So, it seems reasonable to accept that other shoot (Sankula et al., 2004), root system (Ford \& Pleasant, 1994) or allelopathic characteristics (Bertholdsson, 2005) of cotton cultivars reduced gliricidia growth (Table 3). In the case of gliricidia-weed competition, since gliricidia "cultivar" was the same in all treatments, weed growth reduction, due to competition, may have been due to characteristics similar to those indicated for the cotton, as well as plant height, but allelopathy seem to play an important role (Obando, 1987; Kamara et al., 2000).

It can be concluded that twelve weed species predominated in the experiment, many of them belonging to the Poaceae family. Weeds occur at different frequencies and in a non-uniform manner in the experimental area. Cultivars did not influence weed dry matter. Intercropping with gliricidia reduced weed dry matter, but did not prevent reductions in cotton fiber and seed cotton yield, which were higher in hoed plots. Cultivar BRS Safira had the highest fiber yield, but there were no differences between cultivars with regard to seed cotton yield.

\section{LITERATURE CITED}

BASRA, A. S. (Ed.). Cotton fibers: developmental biology, quality improvement, and textile processing. New York: CRC, 1999. $387 \mathrm{p}$.

BERTHOLDSSON, N. O. Early vigour and allelopathy - two useful traits for enhanced barley and wheat competitiveness against weeds. Weed Res., v. 45, n. 2, p.94-104, 2005. 
BUDELMAN, A. The performance of leaf mulches of Leucaena leucocephala, Flemigia macrophylla, and Gliricidia sepium in weed control. Agrof. Syst., v. 6, n. 1, p. 137-145, 1988.

BUHLER, D. D. Weed population responses to weed control practices. I. Seed bank, weed populations, and crop yields. Weed Sci., v. 47, n. 4, p. 416-422, 1999.

CARRUTHERS, $\mathrm{K}$. et al. Intercropping corn with soybean, lupin and forages: weed control by intercrops combined with interrow cultivation. Eur. J. Agron, v. 8, n. 2, p. 225-238, 1998.

CARVALHO, L. P. et al. Seleção massal e porcentagem de fibra em cultivar de algodoeiro colorido. Pesq. Agropec. Bras., v. 40, n. 9, p.895-898, 2005.

DUTT, Y. et al. Breeding for high yield and fibre quality in coloured cotton. Plant Breed., v. 123, n. 1, p. 145-151, 2004.

FONSECA, R. G.; SANTANA, J. C. F. Resultados de ensaio HVI e suas interpretações. Campina Grande: Embrapa Algodão, 2002. 13 p. (Circular Técnica, 66).

FORD, G. T.; PLEASANT, J. Competitive abilities of six corn (Zea mays L.) hybrids with four weed control practices. Weed Technol., v. 8, n. 3, p. 124-128, 1994

FREITAS, R. S. et al. Interferência de plantas daninhas na cultura de algodão em sistema de plantio direto. Planta Daninha, v. 20, n. 2, p. 197-205, 2002

FUKAI, S.; TRENBATH, B. R. Processes determining intercrop productivity and yields of components crops. Field Crops Res., v. 34, n. 3-4, p. 247-271, 1993.

GOMES, J. K. O. et al. Effects of weed control through cowpea intercropping on maize morphology and yield.

Planta Daninha, v. 25, n. 3, p. 433-441, 2007.

KAMARA, A. Y. et al. Selective control of weeds in an arable crop by mulches from some multipurpose trees in Southwestern Nigeria. Agrof. Syst., v. 50, n. 1, p. 17-26, 2000 .

KAUFFMAN, J. B. et al. Biomass and nutrient dynamics associated with slash fires in neotropical dry forests. Ecology, v. 74, n. 1, p. $140-151,1993$

LeCLERG, E. L.; LEONARD, W. H. E; CLARK, A. G. Field plot technique. Minneapolis: Burgess Publication, 1966. $373 \mathrm{p}$

LEMERLE, D.; GILL, G. S.; MURPHY, C. E. Genetic improvement and agronomy for enhanced weed competitiveness with weeds. Aust. J. Agric. Res., v. 52, n. 5 , p. 527-548, 2001.
MCDONALD, G. K. Competitiveness against grass weeds in field pea genotypes. Weed Res., v. 43, n. 1, p. 48-58, 2003.

MENALLED, F. D.; GROSS, K. L.; HAMMOND, M. Weed aboveground and seedbank community responses to agricultural management systems. Ecol. Appl., v. 11, n. 6, p. $1586-1601,2001$

OBANDO, L. Potencial alelopático de Gliricidia sepium (Jacq.) Walp. sobre los cultivos de maiz y frijol y las malezas predominantes (abstract). In: WITHINGTON, D.; GLOVER, N.; BREWBAKER, J. L. (Ed.). Gliricidia sepium (Jacq.) Walp.: management and improvement. Turrialba: Wiamanalo, Nitrogen Fixing Tree Association - NFTA, 1987. p. 59-60.

PUNITHA, D. RAVEEDRAN, T. S. DNA fingerprint studies in coloured cotton genotypes. Plant Breed., v. 123, n. 1, p. 101-103, 2004.

RIBEIRO JÚNIOR, J. I. Análises estatísticas no SAEG. Viçosa, MG: Universidade Federal de Viçosa, 2001. $301 \mathrm{p}$.

SAMPAIO, E. S. V. B.; SALCEDO, I. H. \& SILVA, F. B. R. Fertilidade dos solos do semi-árido. In: PEREIRA, J. R.; FARIA, C. M. B. (Eds.). Fertilizantes: Insumo básico para a agricultura e combate à fome. Petrolina: Embrapa-CPATSA/ SBCS, 1995. 273 p.

SANKULA, S.; VANGESSEL, M. J.; MULFORD, R. R. Corn leaf architecture as a tool for weed management in two corn production systems. Weed Sci., v. 52, n. 6, p. 10261033, 2004.

SILVA, A. A.; VARGAS, L.; WERLANG, R. C. Manejo de plantas daninhas na cultura do milho. In: GALVÃO, J. C. C.; MIRANDA, G. V. Tecnologias de produção do milho Viçosa, MG, Universidade Federal de Viçosa, 2004. p. $269-310$

SINGH, S. et al. Evaluation of mulching, intercropping with Sesbania and herbicide use for weed management in dryseeded rice (Oryza sativa L.). Crop Prot., v. 26, n. 4, p. 518-524, 2007.

TIAN, G; KANG, B. T. Evaluation of Gliricidia sepium prunings for phytotoxicity on maize and cowpea seedlings. Agrof. Syst., v. 26, n. 2, p. 249-254, 1994

WANGHMARE, V. N.; KORANNE, K. D. Coloured cotton: present status, problems and future potentials. Indian J. Gen., v. 58, n. 1, p. 1-15, 1998.

YAMOAH, C. F.; AGBOOLA, A. A.; MULONGOY, K. Decomposition, nitrogen release, and weed control by prunings of selected alley cropping shrubs. Agrof. Syst., v. 4, n. 3, p. 239-246, 1986. 